\title{
Galia Muskmelons: Evaluation for Florida Greenhouse Production 1
}

Nicole L. Shaw, Daniel J. Cantliffe, and Jeanmarie M. Harty ${ }^{2}$

Galia muskmelon (Cucumis melo Reticulatus group L.) is a specialty melon with green flesh and a golden-yellow netted rind, prized for its bold aroma and high sugar content (Fig. 1). While it was developed in Israel for field cultivation, it can be successfully produced in greenhouses or walk-in tunnels (Fig. 2). The primary market is currently Europe; however, field grown Galia melons are being imported into the United States from Israel and Guatemala. The wide distribution has led to Galia being an identifiable trade name for this type of melon. Terminal market prices for Galia melons are substantially higher than those for other specialty melons. For example, on March 26, 2002 at the New York Terminal market, Galia 4s were \$18-20 while Crenshaw 4s were \$14 and Orange Fleshed 6s were $\$ 11$. Also, peak quality in Galia melons requires harvest near the vine-ripe stage, so shorter transport distances should result in increased fruit quality.

\section{Production Methods}

Galia melons can be produced in any greenhouse suitable for growing tomatoes. The gutter height

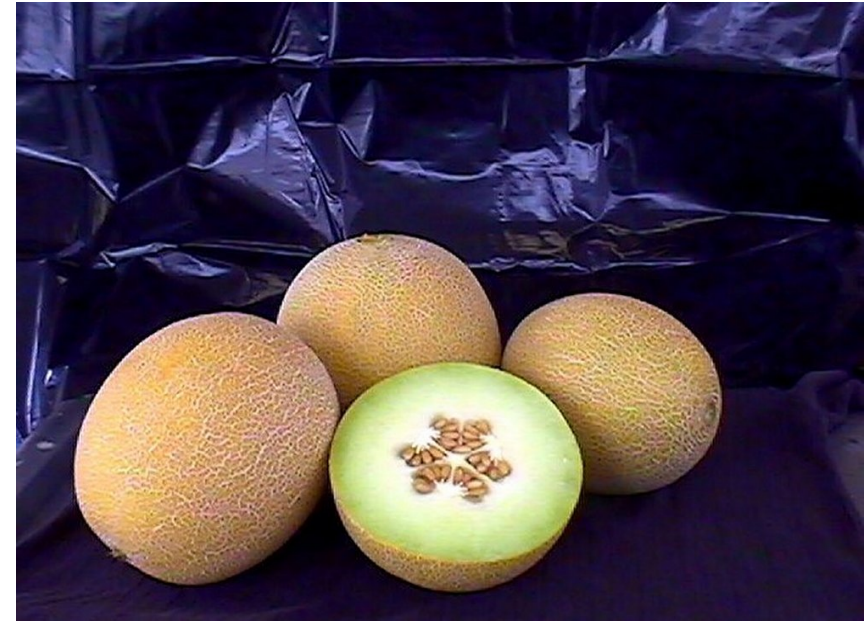

Figure 1. Vine-ripe Galia melons. Credits: Photo courtesy of Juan Rodriguez

should be sufficient to allow good air movement around the plants and to aid in ventilation, preferably greater than 8 feet. Galia melons prefer temperatures in the range of $70-95^{\circ} \mathrm{F}$ and do not yield well when temperatures drop below $60^{\circ} \mathrm{F}$. Best fruit quality is obtained when night temperatures are at the lower extreme within the optimum range.

1. This document is HS919, one of a series of the Horticultural Sciences Department, Florida Cooperative Extension Service, Institute of Food and Agricultural Sciences, University of Florida. Original publication date, July 2001 by Elizabeth M. Lamb, formerly an assistant professor, Horticultural Sciences Department, University of Florida, Indian River Research and Education Center, Fort Pierce, FL. This publication was revised in June of 2009. Visit the EDIS Web site at http://edis.ifas.ufl.edu.

2. Nicole L. Shaw, senior biologist; Daniel J. Cantliffe, distinguished professor and chairman, Horticultural Sciences Department; and Jeanmarie M. Harty, Ph.D. candidate, Horticultural Sciences Department, Cooperative Extension Service, Institute of Food and Agricultural Sciences, University of Florida, Gainesville, FL.

The Institute of Food and Agricultural Sciences (IFAS) is an Equal Opportunity Institution authorized to provide research, educational information and other services only to individuals and institutions that function with non-discrimination with respect to race, creed, color, religion, age, disability, sex, sexual orientation, marital status, national origin, political opinions or affiliations. U.S. Department of Agriculture, Cooperative Extension Service, University of Florida, IFAS, Florida A. \& M. University Cooperative Extension Program, and Boards of County Commissioners Cooperating. Millie Ferrer, Interim Dean 


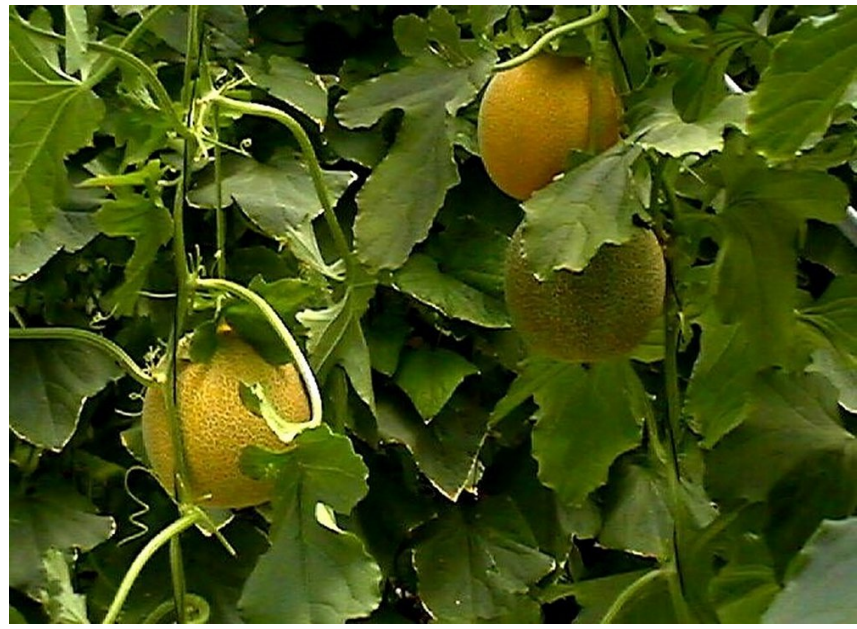

Figure 2. Greenhouse production of Galia melons. Credits: Photo courtesy of Juan Rodriguez

Tests in Florida have demonstrated successful hydroponic production of Galia melons in perlite or pine bark in white polyethylene lay-flat bags (Fig. 3), as well as in 3-gallon nursery pots. Transplants can be produced in a peat:perlite mix and transplanted after 3-4 weeks. In the central Florida area, the fall crop should be planted before the first week of August and the spring crop should be planted mid to late January. (Normal daily mean temperature in Gainesville, Florida is $54^{\circ} \mathrm{F}$ in January and $80^{\circ} \mathrm{F}$ in August.) In other regions, planting dates should reflect local temperatures.

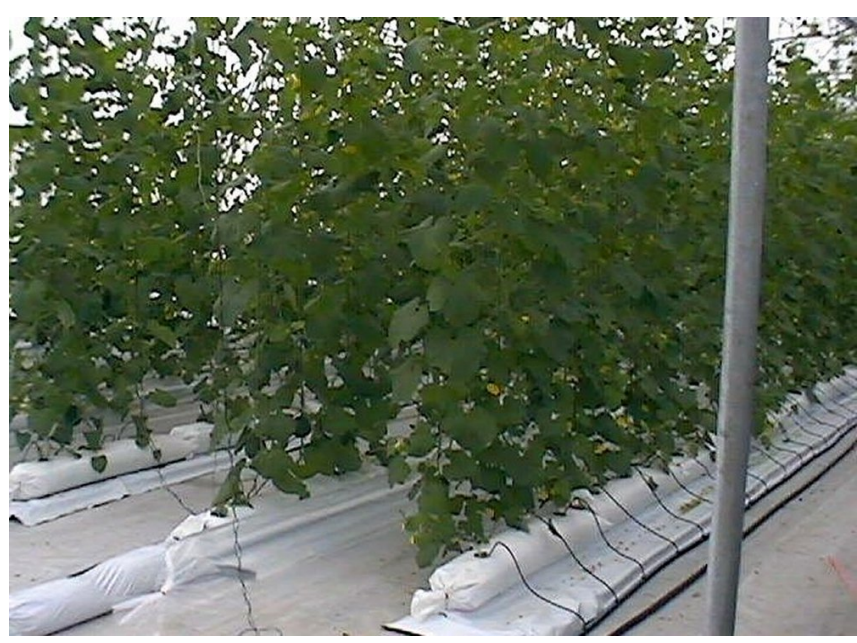

Figure 3. Production of Galia melons in perlite-filled bags. Credits: Photo courtesy of Nicole Shaw

Water and nutrients are delivered through a drip irrigation system with an emitter at each plant. While black irrigation pipe is most common in greenhouse vegetable production, growers in warmer regions have found that using white pipe with a black interior prevents heating of the irrigation water and algal growth. Scheduling of irrigation is based on maintaining a 10-20 percent leach of the total water provided and will vary with plant development, temperature and available sunlight. In general, water use for melon production is greatest during vegetative growth. Sufficient water is necessary during fruit maturation, but excess irrigation can lead to fruit cracking. Irrigation scheduling can be adjusted by changing the frequency of irrigation events, the length of the irrigation period, or both.

Galia melons have been successfully produced in the Gainesville, Florida area using the fertilization schedule provided in Table 1. Environment and production factors may require modifications in the nutrient mix in other regions. Excess nitrogen at transplanting may burn the plants. Preliminary research suggests that a continuous supply of nitrogen throughout the growing season may result in increased fruit yields when compared to changing nitrogen level with growth stage (see website on melon fertigation). Increasing the level of potassium fertilization or raising the solution electrical conductivity (EC) to 3.8 milliSiemens/cm may result in sweeter fruit. The $\mathrm{pH}$ of the nutrient solution should be 5.5-6.5.

Plant spacing should be approximately 12 inches between plants in a single row. Row spacing may depend on trellising height. Tests have shown increased plant yield with 4-foot row spacing when the plants can be trellised to 12 feet $\left(0.25\right.$ plants $/ \mathrm{ft}^{2}$, approximately 10890 plants/acre). If maximum trellising height is no greater than 8 feet, row spacing of 6 feet may be more appropriate $\left(0.17\right.$ plants/ $/ \mathrm{ft}^{2}$, approximately 7400 plants/acre). Plants are pruned to a single stem and can be supported on a nylon net trellis (6-inch by 6-inch openings) or with twine and plastic clips, as in greenhouse cucumber production.

Greenhouse-grown Galia melons require intensive pruning beginning one week after transplanting. Lack of adequate pruning will result in excessively vegetative plants and reduced fruit numbers. All laterals are removed up to the eighth node on the main stem to allow the plant to produce a good base of vegetative growth to support fruit set. Each lateral subsequent to the eighth node is pruned 
after the first fruit is set and has reached golf ball size (Figure 4 arrow indicates where lateral should be pruned). The leaf may be left at the pruned node or removed. Fruit set at the first node on a lateral are often higher quality than those set on subsequent nodes. Therefore, if fruit does not set at the first or second node on a lateral due to poor pollination, temperature imbalances, or inadequate early pruning, it is preferable to remove the entire lateral to encourage fruiting at higher laterals.

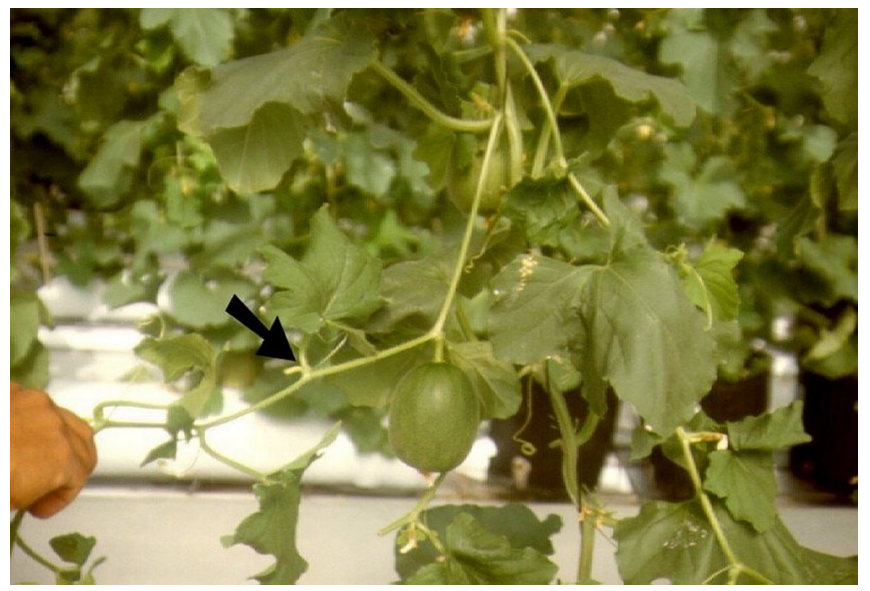

Figure 4. Lateral with developing fruit. Arrow indicates where lateral should be pruned. Credits: Photo courtesy of Nicole Shaw

Bumble bees should be introduced into the greenhouse approximately 2 weeks after planting. Sugar water should be available for supplemental feeding until pollen is available, but it must be removed at that point to encourage pollination. Because of the necessity for insect pollinators, use of insecticides is limited and biological control or insect exclusion should be used where possible. Daily scouting and use of sticky traps to indicate pest population levels are essential. Powdery mildew (Sphaerotheca fuliginea) and gummy stem blight (Didymella bryoniae) must be controlled to maintain yields.

Fruit should be harvested when the rind color is golden-yellow and the fruit are at the full-slip stage for the highest quality. Full-slip indicates that the fruit separates cleanly from the stem under moderate pressure. Fruit quality is determined by fruit size, amount of rind netting, and sweetness (measured as degrees Brix). In the European market, fruit of $1.5-2.2 \mathrm{lb}$ are preferred for Galia melons. While the American market prefers 3-lb or larger field-grown muskmelons, smaller fruit of a high-value, specialty melon type may have greater marketability than larger fruit. In general, well-netted fruit are preferred. Fruit sweetness ratings should be in the range of $11-14^{\circ}$ Brix or higher.

\section{Cultivar Evaluation}

The results of a comparison of cultivars of Galia-type melons are provided in Table 2. The melons were grown in an Israeli sawtooth design, passively ventilated greenhouse covered with double layer polyethylene, located in Gainesville, Florida. The sidewalls were 12 feet high and the peak was 26 feet high. The 3 -foot roof vent and sidewalls were covered with 0.02-inch mesh screen for insect control. Plants were grown hydroponically in perlite-filled polyethylene bags, 3 plants per 1-foot by 3 -foot bag. Additional information on this test is available in the Proceedings of the Florida State Horticultural Society, 114:288-293 or at the Protected Agriculture Web site, http://www.hos.ufl.edu/protectedag under Publications.

The cultivars evaluated were Arava, Gal-152, Gal-52, Galia, Galor, Jalisco, Revigal (Hazera Genetics - Burim, D.N. Shikmim, Israel 79837); Arava, Galia, Golan (Zeraim Gedera - Gedera, Israel 70750); Capri, and Omega (Sunseeds - 18640 Sutter Blvd., Morgan Hill, CA 95038-2078). Cultivars with the same name from different seed companies are designated with the initial of the seed company ( $\mathrm{H}$ for Hazera Genetics and $\mathrm{Z}$ for Zeraim Gedera) in Table 2. Three-week-old plants were transplanted into the hydroponic system on October 14, 1999 and March 3, 2000. There were 9 harvests between January 15 and February 11 in the fall 1999 season. The spring 2000 harvest period extended from May 15 to July 28 with 17 harvests.

Results for total marketable fruit per season, average fruit weight, percent Brix and percent netting are given in Table 2. Although the number of fruit harvested per plant is higher in the spring 2000 season for many cultivars, when adjusted for number of harvests, the values are fairly similar. Experience has shown, however, that spring is a better season for production of Galia melons, due to higher 
temperatures and higher solar radiation. Weight and number of culled fruit were higher for the fall crop. Average fruit weight was consistently higher in the spring season, by $10-90 \%$. Rankings of cultivars by average fruit weight varied by season but Arava $\mathrm{H}$, Arava Z, Gal -152 and Gal 52 were among the top cultivars for fruit weight in both seasons. However, the two Arava cultivars had slightly lower fruit numbers in the spring. For most cultivars, fruit grown in the spring season were sweeter (higher Brix values) and more netted. While Brix values were lower than reported for Galia melons in both seasons, they were within acceptable levels in the spring (cantaloupes with a Very Good internal quality designation for USDA quality standards must have at least 11 percent soluble solids). In general, different sources of the same cultivar did not differ greatly. Choice of cultivar may depend on whether the market is more dependant on fruit size or fruit sweetness.

More recent cultivar trials performed in fall 2005 and spring 2006 screened 15 Galia or Galia-type muskmelon lines. The complete report is available in the Proc. of the Florida State Horticultural Society (Vol. 120,pg 162-167) or at the Protected Agriculture website (www.hos.ufl.edu/protectedag). Transplant and crop production was similar to that previously described, except that the greenhouse was located in Citra, Florida and was covered with only one layer of polyethylene plastic instead of a double layer as used before. The plants were grown in 3-gallon nursery containers filled with screened pine bark media and irrigated with a complete fertilizer solution according to Table 1.

Melons were produced using integrated pest management (IPM) techniques and biological control for insect pests. Some of the most common pests were two-spotted spider mites, whitefly and thrips. These pests were controlled with scheduled releases of predatory mites, parasitic wasps and a generalist predator, Orius insidiosus.

Powdery mildew diseases severity (PMDS) ratings were recorded at the first signs of disease symptoms and continued weekly until the crop was terminated. In order to suppress powdery mildew and keep the plants productive without applications of harsh or systemic chemical fungicides, the plants were sprayed weekly with potassium bicarbonate (Milstop, Bioworks, Inc., Fairport, NY), a product which is safe for bumble bees and most beneficial insects.

Yields were much less than expected due to poor quality of pollination resulting from high greenhouse air temperature $\left(90^{\circ} \mathrm{F}\right)$. Yields were averaged over three plants; many times less than one fruit per plant was recorded in fall and 3 fruits per plant in spring. The cultivar Nestor (Hazera Genetics, Inc.) rated the lowest PMDS and also produced comparable yields and soluble solid levels to the standard Galia cultivar. Though more research should be done before a solid recommendation can be made, Nestor may be a good selection for locations where powdery mildew is problematic. 
Table 1. Nutrient solution for greenhouse production of Galia melons.

\begin{tabular}{||l|c||}
\hline \multicolumn{1}{|c|}{ Nutrient } & Parts per million \\
\hline $\mathrm{N}$ - vegetative growth & $80-100$ \\
\hline $\mathrm{N}$ - at first flower & $120-140$ \\
\hline $\mathrm{N}$ - fruit maturation & $160-180$ \\
\hline $\mathrm{P}$ & 50 \\
\hline $\mathrm{K}$ - vegetative growth & 150 \\
\hline $\mathrm{K}-$ fruiting & 225 \\
\hline $\mathrm{Ca}$ & 120 \\
\hline $\mathrm{Mg}$ & 50 \\
\hline $\mathrm{S}$ & 65 \\
\hline $\mathrm{Fe}$ & 3 \\
\hline $\mathrm{Cu}$ & 0.2 \\
\hline $\mathrm{Mn}$ & 0.8 \\
\hline $\mathrm{Zn}$ & 0.3 \\
\hline $\mathrm{B}$ & 0.7 \\
\hline $\mathrm{Mo}$ & 0.06 \\
\hline \hline
\end{tabular}

Table 2. Harvest data for Galia-type cultivars.

\begin{tabular}{|c|c|c|c|c|c|c|c|c|}
\hline \multirow[b]{2}{*}{ Cultivar } & \multicolumn{2}{|c|}{ Marketable Fruit Per Plant } & \multicolumn{2}{|c|}{$\begin{array}{l}\text { Average Fruit Weight } \\
(\mathrm{oz})\end{array}$} & \multicolumn{2}{|c|}{ Brix } & \multicolumn{2}{|c|}{ Percent Netting } \\
\hline & $\begin{array}{c}\text { Fall } 1999 \\
(9 \text { harvests) }\end{array}$ & $\begin{array}{l}\text { Spring } 2000 \\
\text { (17 harvests) }\end{array}$ & $\begin{array}{r}\text { Fall } \\
1999\end{array}$ & $\begin{array}{l}\text { Spring } \\
2000\end{array}$ & $\begin{array}{l}\text { Fall } \\
1999\end{array}$ & $\begin{array}{c}\text { Spring } \\
2000\end{array}$ & $\begin{array}{c}\text { Fall } \\
1999\end{array}$ & $\begin{array}{c}\text { Spring } \\
2000\end{array}$ \\
\hline Arava-H & 4 & 3 & 22 & 35 & 10 & 11 & 75 & 100 \\
\hline Arava-Z & 3 & 3 & 23 & 34 & 10 & 11 & 75 & 75 \\
\hline Capri & 3 & 3 & 22 & 42 & 10 & 11 & 75 & 100 \\
\hline Gal 52 & 3 & 5 & 25 & 32 & 11 & 11 & 100 & 100 \\
\hline Gal 152 & 3 & 5 & 23 & 31 & 10 & 12 & 75 & 100 \\
\hline Galia-H & 2 & 4 & 22 & 27 & 8 & 12 & 50 & 75 \\
\hline Galiz-Z & 3 & 5 & 22 & 28 & 9 & 12 & 50 & 75 \\
\hline Galor & 2 & 5 & 22 & 30 & 10 & 12 & 75 & 100 \\
\hline Golan & 2 & 5 & 20 & 24 & 11 & 11 & 75 & 100 \\
\hline Jalisco & 3 & 5 & 24 & 30 & 9 & 10 & 75 & 100 \\
\hline Omega & 4 & 5 & 20 & 25 & 11 & 11 & 75 & 100 \\
\hline Revigal & 3 & 5 & 24 & 26 & 10 & 11 & 75 & 100 \\
\hline
\end{tabular}

